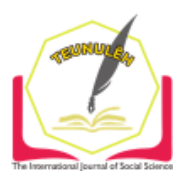

Jurnal Ilmiah Teunuleh

The International Journal of Social Sciences

Vol. 2, Issue. 2, June 2021

E-ISSN: 2746-4393

\title{
EDUCATION INNOVATION MODEL WITH STRATEGY IMPLEMENTATION OF THE "DARE TO BE DIFFERENT" CONCEPT
}

\author{
Muhammad Yusuf ${ }^{1}$, lip Syarifah², Uyu Wahyudin ${ }^{3}$ \\ ${ }^{1}$ Akademi Perekam Medis dan Informasi Kesehatan (APIKES) Sihat Beurata \\ ${ }^{2,3}$ Pendidikan Masyarakat, Fakultas IImu Pendidikan, Universitas Pendidikan Indonesia \\ 1.javirmaulana@gmail.com, 2iip_syarifah@upi.edu, ${ }^{3}$ wahyudin.pls@upi.edu
}

\begin{abstract}
In the face of rapid and complex and unpredictable changes in life, educational innovation must be an important and critical priority because education is still the main support for improving the quality of human resources. The educational innovation model in the Indonesian Ministry of Education and Culture still tends to be more dominant in using a "top-down model" strategy, namely educational innovation developed from above by policy makers from the central level, to be implemented imperatively down to the lowest level of educational institutions. This will dull the creativity of the teaching staff and education staff. Thus, educational innovation should be balanced with a "bottom-up model" strategy, namely a model of educational innovation developed from below, which originates from the creativity of education personnel and educational staff in each educational institution implemented as an effort to improve the quality of education delivery. In order for educational innovation to run faster than other changes, it is necessary to look for more powerful models and strategies through various scientific approaches. The educational innovation model with a strategy of implementing the concept of "Dare to be different" is a concept used to motivate education providers to carry out educational innovations by not contradicting existing educational innovation models and strategies. This model focuses more on internalizing the enthusiasm for educational innovation, especially by educators. Dare to be different means daring to be different, so start with the word dare which stands for the words dream, attitude, relationship, and excellence.
\end{abstract}

Keywords: Educational Innovation, Dare to be Different

\section{A. Introduction}

It is time for educational innovations in Indonesia to come from education practitioners in the field, especially in the global era where various problems have 
demanded various basic educational changes. The climate of life as a nation and state which is not conducive, which tends to lead to uncontrolled freedom has caused various problems in various fields of life, including education. In the grass-roots system this has caused various social symptoms and problems. Our education still seems chaotic and inequality, both in quality, quantity, and in relation to the effectiveness and relevance of education, some even think that our education is very chaotic, with no clear direction and purpose. Our current National Education will experience a wider failure in shaping the values of the nation's character towards students, if it is allowed to be more oriented towards the formation and development of the cognitive domain, and even if it is not developed comprehensively, it is limited to the low level cognitive domain.

The results of the latest international study on the ability of Indonesian students in the international arena. The results of the survey "Trends in International Math and Science" in 2007, conducted by the Global Institute, showed that only five percent of Indonesian students were able to work on high category reasoning problems; whereas Korean students can reach $71 \%$. In contrast, $78 \%$ of Indonesian students can do low category memorization questions, while $10 \%$ of Korean students. Other data revealed by the Program for International Student Assessment (PISA), the results of its 2009 study put Indonesia in the bottom 10 of the 65 PISA participating countries. Facing these various problems and challenges, it is necessary to change and organize the education system as a whole and comprehensively, especially with regard to the quality of education, and its relevance to the needs of society and the world of work.

In Indonesia, various efforts have been made by the government to achieve ideals in the field of education as mandated by the opening of the 1945 Constitution, namely to educate the nation's life. These efforts are made in the form of reforms or innovations in the field of education. For this reason, the government issues policies in education. These policies are contained in the 1945 Constitution, programs, laws, government regulations, ministerial regulations, and so on. Many of these policies have been issued by the government, of which some are related to Educational Innovation.

There have been quite a number of government policies related to educational innovations that have been carried out, including: Active Student Learning Method (CBSA); Pamong Teachers, School Development Pilot Project (PPSP) at the SD, SMP and SMA levels; Small School; Modu Teaching System; Open University Distance Learning System (SBJJ); stipulation of National Education Standards; National Education Standards Agency; Teacher career development (Certification); and also the Lesson Study 
Development. The latest changes and innovations made by the government are replacing PP No. 19 of 2005 to PP No. 32 of 213 and Changing the KTSP curriculum (curriculum 2006) to the 2013 curriculum, which was later moratorium for evaluation, and now changed to the National Curriculum (Kurnas).

How to make educational innovation experience continuous progress (continues progress), it is necessary to find solutions and strategies that are oriented towards internalizing the spirit and work ethic of educational actors in various, pathways, and levels of educational institutions. Educational innovation must be carried out in a structured, systematic, massive, orderly, safe and successful manner.

Structured means that it must be pursued through an organized system in an efficient and effective organizational structure and work procedure (SOTK) which is equivalent to the low cost high impact theory, with limited capital (energy, time, cost) but produces a large and wide impact. Systematic means that there is clarity of work stages in terms of goals, targets, targets, strategies, and evaluations, in the form of a system that can be used as a guide for everyone involved in educational innovation activities. Massive means that educational innovation must mobilize and utilize all resources (human, money, material, etc.) to actively participate so that educational innovation becomes the interest of all parties. Orderly means obeying principles, working based on rules and regulations that apply as a juridical aspect in education starting from the 1945 Constitution, Laws, PPs, Kepres, Kepmen, up to the rules of educational institutions at the executive level. Safe means that it does not cause noise and disorderly implementation of education. Success means being marked by various successes in educational innovations that are measured objectively and scientifically.

\section{B. DISCUSSION}

\section{Innovation Concept}

Innovation comes from the Latin word, innovation which means renewal and change. The verb is innovo which means to renew and change. Innovation is a new change that leads to improvement; which is different or different from the previous one, which is done on purpose and plan (not by chance). The word "innovation" (English) is often translated as anything new or renewal (Hamijoyo, 1996), but some have made the word innovation become the Indonesian word is "innovation". Innovation is sometimes used to express discovery, because new things are the results of discoveries. The word invention is also often used to translate the words from the English language "discovery" 
and "invention". There is also a link between the meaning innovation and modernization, because they both discuss reform efforts.

In order not to confuse readers and to broaden their horizons and clarify the meaning of educational innovation, it is necessary to first discuss the meaning of discovery, invention, and innovation. The three terms in Indonesian can be interpreted as "discovery", which means the discovery of something new, it may be something. The new one has been around for a long time, but then it is only discovered or known, or maybe something new was really not there before or not yet found, because for certain purposes something really new is made, even by using discovery or invention.

Discovery is the discovery of something that actually found objects or things that already exist, but are not yet known to people. For example, the discovery of the American continent. Actually, the American continent has been around for a long time, but it was only discovered by Columbus in 1492, then it is said that Columbus discovered the American continent, meaning that Columbus was the first European to encounter the American continent. Invention is the discovery of something completely new, meaning that The results of human creations, objects or things that were encountered really didn't exist before, then they were held with new creations. For example, the discovery of learning theories, educational theories, techniques for making plastic goods, fashion clothes, and so on. Of course the emergence of ideas or creativity based on observations, experiences, from things that already exist, but the form he finds is really new.

Innovation is an idea, item, event, method that is felt or observed as something new to a person or group of people (society), whether it is in the form of invention or discovery. This is in line with the opinion of Donald P. Ely (1982) which states "An innovation is an idea for accomplishing some social recognition and in a new way or for a means of accomplishing some social", and the opinion of Zaltman, Duncan, (1977: 12 ) which states "An innovation is any idea, practice, or material artifact perceived to be new by the relevant unit of adopt. The innovation is the change object. A change is the altera in the structure of a system that requires or could be required relearning on the part of the actor (s) in response to a situation. The requirements of the situation often involve a res to a new requirement is an inventive process producing an invention. However, all innovations, since not everything an individual or formal or informal group adopt is perceived as new ". So innovation can be defined as an idea, item, event, method that is felt or observed as something new to a person or group of people (society), whether it is 
the result of an invention or a coverage. Innovation is held to achieve certain goals or to solve a particular problem.

According to Hamidjojo, quoted by Abdulhak (2002), educational innovation is "a change that is new and qualitatively different from the previous one and is deliberately made to increase the ability to achieve certain goals, including in the field of education". Innovation is not just a change from one state to another. In changes that are classified as innovation, in addition to new ones, there must be an element of intent, an element of quality that is better than before and is directed at increasing various abilities to achieve the expected goals. Educational innovation is innovation in the field of education or innovation to solve educational problems. Educational innovation is basically a change or brilliant thinking in the field of education which is characterized by new things or in the form of certain educational practices or in the form of a product of a result of thought and technology applied through certain stages that are believed and intended to solve educational problems which arise and improve a state of education or a certain educational process that occurs in society.

\section{Educational Innovation Model}

In general, there are two educational innovation models, namely: a. Top-down models, namely educational innovations created by certain parties as leaders / superiors that are applied to subordinates; as well as educational innovations undertaken by the Ministry of National Education so far; b. The bottom-up model is an innovation model that is sourced and created from below and implemented as an effort to improve the delivery and quality of education.

\section{Educational Innovation Goals}

According to Hamidjojo (1974) the main objective of innovation is to increase the resources of manpower, money and facilities, including organizational structures and procedures. The purpose of educational innovation is to increase the efficiency, relevance, quality and effectiveness of facilities as well as the maximum number of students with the greatest possible educational outcome (according to the criteria for the needs of students, society and development) by using resources, energy, money, tools and time the smallest thing.

Systematically, the direction of the aims of Indonesia's educational innovation are:

a. Catch up with various lags from various advances in science and technology, so that ultimately education in Indonesia is increasingly running parallel to these advances. 
b. Endeavor to carry out education in every type, track and level that can serve every citizen equally and fairly.

c. Reforming the Indonesian education system to be more efficient and effective, respecting national culture, smooth and perfect policy information systems, strengthening national identity and awareness, fostering a community to love to learn, attracting students' interest, and producing many graduates who are really needed in various fields jobs that exist in people's lives.

\section{The concept of Dare to be Different}

Dare to be different, can be interpreted as being brave to be different, or a courage to be extraordinary. From verb DARE can be created as an acronym for: Dream, Attitude, Relationship, and Excellence. How to make educational innovation successful, the following steps must be used:

1) Dream means dreams, aspirations, desires, goals, goals that will be achieved by a person or group of people in an organization, like a football player will be eager to bring the ball to the target / goal in order to set a winning goal. Dreams are desires that are very, very coveted and must come true regardless of the risk. With dreams, all activities will be filled with extraordinary enthusiasm.

2) Attitude, which means attitude, which is a person's tendency to a problem, or a person's perspective on every life problem and life they face. Attitudes are divided into two, namely positive attitudes and negative attitudes. Positive attitudes tend to focus more on the positive things of a problem so that it creates pleasure and calmness, while negative attitudes tend to focus more on negative things, shortcomings, ugliness, which creates dislike and weakens the spirit of work.

3) Relationship, meaning connectivity, relations, networking, or friendship. With whom we make relationships and work together will determine our success in the future. 4. Excellence, which means perfection, especially in chasing dreams, you don't need to wait for everything to be completely complete, ready and perfect. The most important thing is to straighten your intentions, complete your efforts, and trust in Allah SWT.

4) Different, means different, applying a principle if not better make it different so that you will be noticed by other people.

Dream has extraordinary power, wise people say the characteristic of a human being is having a dream, dream that has power, dream is your compass, dream develops your potential, dream helps organize your priority, dream adds value to the job, dream 
helps design future. Because of that, take care and take care of your dreams, beware of your dream thieves who are usually the people closest to you and seem to love you. If you follow the clockwise direction you will not change much, if you want to change fast forward and safe, follow the direction of your compass needle.

\section{Strategy for Implementing the Concept of "Dare To Be Different" in Educational Innovation}

Any educational innovation model will be very effective if it starts with a strategy of implementing the concept of "Dare To Be Different". Educational innovation must have clear goals, goals and objectives. The dream of educational innovation must be made with the following criteria: Big, valuable, and smart (specific, measurable, achievable, rationable, and time limited). Big and valuable dreams will generate great enthusiasm and value from the actors of educational innovation. Dreams in educational innovation are hopes or desires that are very coveted and must come true regardless of the risk.

Therefore, a good dream besides being big and valuable, must meet the following criteria: 1) Specific means specific, clear indicators of achievement, can be quantified; 2) Measurable, meaning the level of achievement can be measured; 3) Achievable, meaning that the dream is likely to be achieved; 4) Rationable, which means that the dream is reasonable or rational, not grandiose, not an empty wishful thinking; and 5) Time limited, meaning that the dream has the required duration of clarity, there is certainty when it will be achieved. This smart dream is what will leverage the enthusiasm of educators and educational institutions in carrying out educational innovations, both at the planning stage, during implementation, as well as in the hold on evaluation and follow-up.

After the dream, educators and education personnel who are involved in educational innovation must be ensured to have a positive attitude towards educational innovation. There are quantification results of various factors that support the success of educational innovation, by means of quantification if $A=1, B=2, C=3$, etc. $Z=26$, it turns out that the factor: Luck $=47 \%$, Love $=53 \%$, Money $=72 \%$, Knowledge $=96 \%$, Leadership $=97 \%$, Hard Work $=98 \%$, and apparently Attitude $=100 \%$. This means that the $100 \%$ determinant factor contributing to the success of educational innovation is the attitude.

Attitude is everyone's emotional intelligence as a determinant of success. Attitudes are: the "forerunner" of our true self, the root is in the mind, but the fruit comes out; Our best friend or worst enemy; More honest and more consistent than our words; 
External views based on past experiences; That which attracts others to us or drives them away; Never satisfied before stated; Our past librarian; Our present spokesperson; even like our future prophet.

If a positive attitude is embedded in innovators, a work atmosphere that is fun, full of optimism, full of beauty, full of hope and far from despair at work, will be accompanied by a race of gratitude for any educational innovation activities that have been carried out. It is different if a negative attitude is embedded, it can be ascertained that educational innovation will stop and fail because what is seen by educational innovation actors are deficiencies, obstacles, threats, and other negative things, this will give rise to hatred and dislike at work, even it can leads to depression and indifference.

According to Widayatun, TR (1999: 223) there are 8 functions of attitude, namely: as instrumental; self defense; recipient of objects, knowledge, and giving meaning; expressive value; social adjustment; externalization; adaptive activities in obtaining information; life reflex. In contrast to Katz's (1960) opinion quoted in Maramis, Willy F. (2006: 257) attitudes have 4 functions, namely:

\section{a) Adjustment function}

An attitude can be maintained because it has useful helpful values; allows individuals to reduce punishments and increase rewards when dealing with those around them. This function is related to the theory of the learning process.

\section{b) The defense function of the ego}

This function is related to Sigmund Freud's theory, which explains that this attitude "defends" the individual against unpleasant or threatening information, otherwise he must face it.

\section{c) Value expression function}

Some attitudes are held by a person because they embody the core values and self-concept. We all think of ourselves as this or that kind of person (whether or not they really are is another matter); by having a certain attitude that presumption is supported.

\section{d) Knowledge function}

We must be able to understand and organize the world around us. An attitude that can help this function allows the individual to organize and shape some aspects of his experience.

After attitude, then relationship implementation strategy, meaning that with whom we have to establish relationships and cooperation in implementing educational innovation, without the right relationship it is impossible for educational innovation to 
succeed. Building mutually beneficial relationships and cooperation (win-win solutions) with all education stakeholders will be able to accelerate the achievement of educational innovation goals.

Relationship is a relationship that occurs between one or more. In the process of educational innovation, relationship cannot be avoided, given that they support each other. The relationship in question is the relationship between educational institutions and educational implementers, the relationship between the program and program implementers, the relationship between the curriculum and curriculum implementers and so on. In other words, relationship is a relationship or relationship that supports the achievement of educational innovation. Relationship in the educational innovation process refers to the relationships or factors driving the creation of educational innovation. In other words, an innovation will not be successful if it is not supported by other factors.

According to a survey of interested experts, a person's success in society is $15 \%$ determined by intelligence, skills and technology, the remaining $85 \%$ is determined by how he builds relationships or relationships with various parties that are needed. Based on the results of research from the Stanford Research Institute, that the sale of a product is only $12.5 \%$ determined by knowledge and $87.5 \%$ determined by the ability to deal with other people. In Islamic business, it is known as friendship, with friendship there will be relationships based on high trust and affection, this friendship can also be used in educational innovation.

There are several things that must be considered in making a relationship, including: 1 . With whom we have a relationship (with whom we have a relationship; 2 . Repare your ears to hear); 3. Give others the chance to speak (Give others the opportunity to talk); 4. Ignore weaknes use kindness (Ignore weaknesses, take advantage of kindness); 5. Love and kindness (affection and kindness); 6. Attitude and hospitality (polite and kindness); 7 Thankfulness and rewards (gratitude and appreciation) 8. Consider the wright words (Consider the right words), and 8. Integrity (Integrity, the suitability of words and deeds, the character of honesty, which causes a high level of trust in a person. from other parties These eight aspects should really be used as guidelines in building relationships by educational innovation actors at various levels of educational institutions.

Excel can be interpreted as perfection, excellence, the best quality. When we measure the peak of the success of educational innovation as something excelent, it is 
necessary to pay attention to the following guidelines: 1. Excellence is not money (Perfection is not talking about money); 2. Excellence is not determined by situation (Perfection is not determined by circumstances); 3. Excellence doesn't mean to have all (Perfection doesn't mean having everything); 4. Road to excelence (the long road to perfection).

Different, can be interpreted differently in a positive way, so that it becomes people's attention, make a difference if it can't be better. By implementing the dare to be different concept strategy, educational innovation should run successfully. Education will experience changes and renewal. The difference is, if there is an element of intent in the renewal. The equation is that both have new or different elements from before. Educational reform itself is a change that is new and qualitatively different from what was before it and deliberately attempts to increase the ability to achieve certain goals in education.

To clearly understand the difference between innovation and change, we can see the definition expressed by Nichols (1983: 4): "Change referencing to" continuous reapraisal and improvement of existing practice which can be considered as part of the normal activity... .. while Innovation Refer to.... Idea, subject or practice as new by an individual or individuals, which is intended to bring about improvement in relation to desired objectives, which is fundamental in nature and which is planned and deliberate.

Nichols emphasizes the difference between change (change) and innovation (innovation) as he said above, that change refers to the continuity of assessment, interpretation and hope in improving the implementation of existing education which is considered a normal part of activity. , the object or practice of something new by a person or group of people who intends to improve the expected goals.

Wojowasito, (1992) states: "Everything that is new or renewal is called innovation in Indonesian called innovation". Innovation is an idea, item, event, method that is felt or observed as something new, for a person or group of people (society). Innovation is held to achieve certain goals or to solve a particular problem. Innovation is sometimes also used to express discovery, because the novelty is the result of discovery. The word invention is also often used to translate the English words "discovery" and "invention".

\section{Education System Innovation in Indonesia}

The innovation of the education system in Indonesia is carried out using a juridical approach and a curriculum development approach. Changes to PP No. 19 of 2005 to PP No. 32 of 2013 The government has made efforts to improve the education system, both 
through structuring software (software) and hardware (hardware). These efforts include the issuance of the National Education System Law of 2003, and Government Regulation No. 19 of 2005 on National Education Standards (SNP), which have been reorganized in Government Regulation No. 32 of 2013. In this educational system innovation the government wants a vision, mission and strategy.

Vision, mission and strategy, as well as goals must be clear, feasible, and achievable with existing abilities, and have insight into the ideal picture of the expected educational conditions in the future. Amendment to PP No. 32 of 2013 which previously was PP No. 19 of 2005 concerning National Education Standards, came into effect on May 7, 2013, Based on the preamble in this regulation, the amendment to this regulation is based on the consideration that Government Regulation Number 19 of 2005 concerning National Education Standards needs to be aligned with the dynamics of community, local, national and community development. global in order to realize the functions and goals of national education, as well as the need for a national commitment to improve the quality and competitiveness of the nation. If we look at the contents of PP No. 32 of 2013, it appears that the changes made are more likely to be related to articles related to curriculum and learning (graduate competency standards, content standards, process standards, and assessment standards). This can be seen clearly by the insertion of CHAPTER XIA which specifically contains articles regulating the curriculum. Several articles in PP. 19 of 2005 which was deleted also seems to better illustrate the consequences of the contents of the articles as outlined in this CHAPTER XIA.

Meanwhile, for articles relating to the standards of educators and education personnel, standard of facilities and infrastructure, management standards, and standard of financing, essentially there do not seem to be many significant changes. replace the current curriculum by continuing the national exam.

However, there is something interesting and so visible in this change in government regulations, namely regarding the National Examination (UN) for Elementary School (SD) level, in this new PP, the National Examination at SD level is removed. According to PP 32/2013 Article 67 Paragraph (1a) PP No. 32/2013, the Government assigned BSNP to organize National Examinations for students to participate in in each formal education unit for primary and secondary education and non-formal equivalence pathways. The National Examination for formal education units for basic education as intended, is exempted for SD / MI / SDLB or other equivalent. 
In Government Regulation Number 32 Year 2013, it even explicitly removes the provisions of Article 70 Paragraph $(1,2)$ of PP No. 19/2005, in which it mentions the material for the National Examination at the SD level and equivalent, previously the subjects of Indonesian Language, Mathematics, and Natural Sciences (IPA). According to Article 72 Paragraph (1) of this PP, students are declared to have passed the education unit in primary and secondary education after: a. Complete all Learning programs; b. Obtain a good minimum score on the final assessment for all subjects; c. Pass the school / madrasah exam; d. Pass the National exam.

Even though we know that there is a link between the Curriculum and the UN. The Assessment Process (including the UN) is part of the curriculum. UN and School Exams are part of the assessment and Assessment is an evaluation tool that serves as a feedback source for the achievement of National Education Standards. In a new Government Regulation It also revises eight National Education Standards. The similarity between PP 19/2005 and PP 32/2013 is that of the eight national education standards, there are 4 standards that are still maintained and have not been changed, four standards that have not been changed, namely: a. Education personnel standards, b. Financing Standard, c. Management Standards, and d. Standard of Facilities and Infrastructure. Meanwhile, the four standards that were changed from PP 19 of 2005 by PP 32 of 2013 are: a. Content Standards, b. Process Standards, c. Graduate Standards, and d. Assessment Standards. The most important thing for us to look at in Government Regulation Number 32 of 2013 is the standard for assessing learning outcomes. This new Government Regulation only states that assessment of learning outcomes is used for:

a. Assessing the achievement of student competencies;

b. Materials for preparing progress reports on learning outcomes; and

c. Improve the learning process.

Innovation with a Curriculum Development Approach is needed because of the various challenges faced, both internal and external. In addition, in facing the demands of the times, it is necessary to improve the mindset and strengthen curriculum governance as well as deepening and expanding the material. And the thing of learning that is no less important is the need to strengthen the learning process and adjust the learning load in order to ensure a match between what is desired and what is produced.

In the Elucidation of Law Number 20 of 2003 concerning the National Education System in the General Section it is explained that educational reform requires a specific 
strategy, and one of these national education development strategies is "development and implementation of a competency-based curriculum."

Article 35 of Law Number 20 of 2003 also stipulates that "National education standards are used as a reference for curriculum development, education personnel, facilities and infrastructure, management, and financing." Furthermore, in the explanation of Article 35 it is stated that "graduate competence is a qualification of the ability of graduates. which includes attitudes, knowledge, and skills in accordance with agreed national standards. "

In essence, Law Number 20 of 2003 concerning the National Education System in Article 1 Paragraph (1) states that "Education is a conscious and planned effort to create an atmosphere of learning and the learning process so that students actively develop their potential to have religious spiritual power. self-control, personality, intelligence, noble character, and skills needed by him, society, nation and state.

The dialogue about changing the curriculum from the KTSP Curriculum to the 2013 Curriculum raises questions about teacher professionalism. Curriculum changes since Indonesia's 11th independence have followed the same pattern of flowing from top to bottom. From the concept it flows downward and must be implemented in schools by the teachers. This change is in fact contrary to the nature of education, which is a practical theoretical science. This means that education is a process that is implemented in the field or in the classroom and from this process it will provide input to changing concepts. Therefore the failure of a curriculum concept lies in the implementation of teachers in the field. It is not surprising that various failures in curriculum improvement are blamed or lies on the responsibility of the teachers. The success of the 2013 Curriculum will lie with the teachers and not with anyone else. The development of the 2013 curriculum is continuously being carried out and has now changed to the National Curriculum (Kurnas). In addition, at the tertiary level that has LPTKs (Educational Personnel Education Institutions) such as IKIP, FKIP, STKIP, a systematic review of the LPTK curriculum is based on the KKNI (Indonesian National Qualification Framework).

\section{Conclusion}

Educational innovation is a necessity in facing life changes in various aspects that are getting faster and more complicated and difficult to predict. Educational innovation must be oriented towards improving the quality of education in all its aspects, based on 
Muhammad Yusuf, lip Syarifah, Uyu Wahyudin

the low cost high impact theory, with the lowest possible cost but having a broader impact.

Educational innovation tends to be successful if a structured, systematic, massive, orderly, safe and successful approach is applied. The educational innovation model in the Indonesian Ministry of Education and Culture tends to be more dominant in using the "top-down model" strategy, namely educational innovations developed from above to the ministerial level. This should be balanced with a "bottom-up model" strategy, namely a model of educational innovation developed from below, which originates from the creativity of education personnel and educational staff in each educational institution implemented as an effort to improve the quality of education delivery. In order for educational innovation to run faster than other changes, it is necessary to look for more powerful models and strategies through various scientific approaches.

The educational innovation model with a strategy of implementing the concept of "Dare to be different" is a concept used to motivate education providers to carry out educational innovations by not contradicting existing educational innovation models and strategies. This model focuses more on internalizing the enthusiasm for educational innovation, especially by educators. Dare to be different means daring to be different, so start with the word dare which stands for the words' dream, attitude, relationship, and excellence.

Create big, valuable, and smart dreams in order to create a strong work ethic in educational innovation, instill a positive attitude in educational innovation actors, build relationships and cooperation with various parties as needed, and achieve perfection or excellence from educational innovations that have been made. Educational innovation in Indonesia is carried out with a juridical approach and a curriculum development approach, which is applied in all types, pathways and levels of education. LPTK curriculum innovations continue, the last one is based on KKNI (Indonesian National Qualifications Framework).

\section{Bibliography}

Arifin, Z. (2013). Konsep dan Model Pengembangan Kurikulum. Bandung: PT. Remaja Rosdakarya.

Fattah, N. (2009). Landasan Manajemen Pendidikan. Bandung: PT Remaja Rosdakarya. 
Education Innovation Model With Strategy Implementation of the...

Hamalik, O. (2003). Kurikulum dan Pembelajaran. Jakarta: PT Bumi Aksara.

Harmadi. (2009, January 9). Landasan Kebijakan Pemerintah dalam Teknologi Pendidikan. Retrieved from Harmadi's Blog: http://harmadiderasid.blogspot.com/2009/01/landasan-kebijakan-pemerintah-dalam.html

Imran, A. (1996). Kebijaksanaan Pendidikan di Indonesia; Proses, Produk, dan Masa Depannya. Jakarta: Bumi Aksara.

Irianto, Y. B. (2012). Kebijakan Pembaharuan Pendidikan. Jakarta: Rajawali Press.

Markee, N. (1997). Managing Curricular Innovation. United Kingdom: Cambride University press. Retrieved from http//www. file.upi.edu/ Direktori/FPBS.com

Sa'ud, U. S. (2012). Inovasi Pendidikan. Bandung: CV. Alfabeta.

Subadi, T. (2011). Inovasi Pendidikan. Surakarta: Muhammadiyah University Press.

Sukmayadi, D. (2004). Cakrawala Inovasi Pendidikan Upaya Mencari Model Inovasi. Bandung: Program Pascasarjana Universitas Pendidikan Indonesia.

Tilaar, H. (2009). Kekuasaan dan Pendidikan: Manajemen Pendidikan Nasional dalam Pusaran Kekuasaan. Jakarta: Rineka Cipta.

Tilaar, H. (2012). Pendidikan Nasional: Arah Kemana? Jakarta: PT. Kompas Media Nusantara.

Timotius, A. T. (2008). Dare to Change. Jakarta: Metalexia Publishing.

Wijaya, C., Djanuri, D., \& Rusyan, A. T. (1988). Upaya Pembaharuan dalam Pendidikan dan Pengajaran. Bandung: Remadja Karya. 